\title{
Hva kan helsepersonell gjøre med sosiale helseforskjeller?
}

\author{
Det er mulig å utviske sosiale helseforskjeller i løpet av en generasjon. Men hvilken rolle skal helsetjenesten \\ og helsefagarbeidere ha i dette arbeidet? Og hvordan kan helsefaglige utdanninger forberede oss mot de \\ sosiale helseutfordringene vi står overfor?
}

\author{
Unni Gopinathan \\ unni.gnathan@gmail.com \\ Det medisinske fakultet \\ Universitetet i Oslo \\ og \\ Norsk medisinstudentforening \\ Johanne Helene Iversen \\ Det medisinske fakultet \\ Universitetet i Bergen \\ og \\ Norsk medisinstudentforening
}

Det er godt dokumentert at utdanningsnivå, yrke og inntekt i stor grad bestemmer helsetilstanden til individer og populasjoner (1-3). Sosiale ulikheter i helse kan beskrives som systematiske forskjeller i helsetilstand gjennom hele den sosiale stigen i befolkningen samt helseproblemene til spesielt utsatte grupper og geografiske forskjeller i helse (4). De sosiale ulikhetene i helse utfordrer grunnleggende prinsipper for rettferdighet og kjennetegn ved et velfungerende samfunn.

Oppmerksomheten om problemstillingen har økt de siste årene, men kunnskap om sosiale helseforskjeller er ikke en ny ting. Allerede på 1800-tallet ønsket sosialmedisinens far, Rudolf Virchow (1821-1902), å sette søkelys på samfunnsbetingede årsaker til sykdomsutvikling. Han mente at legen og andre helsearbeidere hadde en klar rolle i dette. Denne måten å tenke på hadde imidlertid ikke like stor innflytelse på medisinutdanningen og utøvelse av medisinsk praksis som Flexner-rapporten (5), utgitt av amerikaneren Abraham Flexner (1866-1959) i 1910. Rapporten introduserte moderne vitenskap som et fundament for medisinutdanningen samt at forskning ikke skulle anses som et mål i seg selv, men noe som skulle forbedre medisinsk praksis og pleie. Studentene skulle ikke lenger bare forstå hvordan man gjorde ting praktisk i medisinen, men også de underliggende biologiske mekanismene som lå bak sykdomsprosesser. Imidlertid fikk ikke rapporten betydning for hvordan medisinsk praksis kunne utøves for å minske ulikheter i helse mellom ulike sosiale klasser og utjevne helseforskjeller i befolkningen - og dermed oppnå «helse for alle».

\section{Helse for alle}

Alma Ata-erklæringen fra 1978 (6), vedtatt under den internasjonale konferansen om primærhelsetjenester som ble arrangert av Verdens helseorganisasjon (WHO), står som en viktig milepæl for folkebevegelser som har arbeidet for å utjevne globale og sosiale helseforskjeller. Deklarasjonen satte primærhelsetjeneste som det viktigste midlet for å oppnå «helse for alle innen år 2000». Punkt 2 i deklarasjonen slo fast at ulikheter i helse eksisterte både mellom land og innenfor land grunnet uakseptable politiske, sosiale og økonomiske årsaker. Deklarasjonen fikk imidlertid ikke den innflytelsen den kunne ha hatt, og det skulle ta 30 år før WHO igjen tok opp prinsippene fra Alma Ata-erklæringen og primærhelsetjenester som et nødvendig virkemiddel for å oppnå helse for alle (7). I tillegg ble Alma Ata-deklarasjonen godt støttet av en ny rapport som hadde som mål å utøve innflytelse på politikkutforming for helse.

Kommisjonen for sosiale helsedeterminanter, nedsatt av forrige generaldirektør for WHO, Jee-Wong Lee, skulle systematisere tilgjengelig viten og kunnskap om hvordan sosioøkonomi påvirker helse samt foreslå mulige tiltak for å oppnå helse for alle. Ledet av sir Michael Marmot konkluderte kommisjonen med at sosiale ulikheter $\mathrm{i}$ helse var unødvendige helseforskjeller og et rettferdighetsproblem. Ifølge dem ville det være mulig å utviske sosiale helseforskjeller i løpet av en generasjon, dersom myndigheter, sivilsamfunn, WHO og andre verdensomspennende organisasjoner gjennomførte tiltakene som de foreslo (1).

I 2011 ønsker WHO å følge opp kommisjonens arbeid med å avholde en verdenskonferanse om sosiale ulikheter i helse i Rio de Janeiro i oktober 2011. Det gjenstår å se hvordan sosiale ulikheter i helse skal bekjempes på globalt plan.

I Norge startet Helsedirektoratet i 2004 et arbeid mot sosiale ulikheter i helse. De har produsert en rekke publikasjoner der man dokumenterer de sosiale helseforskjellene i Norge, og de har også over lengre tid hatt en ekspertgruppe som nylig har endret navn til Fagråd for sosial ulikhet i helse. Det er vist at høyere sosioøkonomisk status i Norge er forbundet med økt bruk av og tilgang til helsetjenester, f.eks. i form av mer tid inne hos legen og flere utførte prøver, som bildediagnostikk $(8,9)$. Sosioøkonomisk status er også vist å være svært viktig for hvordan man klarer å nyttegjøre seg medisinsk kunnskap, informasjonskampanjer om helse og helserisikoer som man kan utsette seg for. Regjeringen har utpekt sosial ulikhet $i$ helse til et nasjonalt satsingsområde, med et klart mål om å redusere helseforskjellene (10).

Både den norske strategien og til dels rapportene fra WHO og Helsedirektoratet har gitt helsetjenesten en begrenset rolle i utjevning av sosiale helseforskjeller. Dette begrunnes med at disse forskjellene først og fremst skyldes faktorer som ligger utenfor selve helsesektoren, og at samarbeid på tvers av sektorer er viktigst for å bekjempe sosiale helseforskjeller. Det er imidlertid bemerkelsesverdig at man ikke har gitt helsearbeidere en klarere rolle i dette arbeidet og i nasjonale strategier, da det faktisk er de som arbeider $i$ front og møter de sosiale helseutfordringene i den daglige praksisen.

\section{Helsearbeidernes rolle}

Den britiske legen Julian Tudor Hart (f. 1927) presenterte allerede i 1971 teorien om at det finnes en invers sammenheng mellom behov for og bruk av helsetjenester (11). De som trengte helsetjenester mest, var de som fikk minst. I teorien betyr dette at mønsteret $\mathrm{i}$ bruken av helsetjenester kan forsterke ulikheter som allerede finnes som følge av sosiale helsedeterminanter. Bringedal \& Bærøe har undersøkt norske legers holdninger til sosiale ulikheter (12). De ønsket å studere om legene tar hensyn til sosioøkonomiske faktorer i møte med enkeltpasienter, hvordan de eventuelt gjør det og om de mener at leger bør ta slike hensyn. Resultatene var motstridende. F.eks. var $82 \%$ av legene helt eller delvis enig i påstanden om at pasienter med lik medisinsk status bør få nøyaktig den samme helsehjelpen, uavhengig av sosioøkonomiske livsbetingelser. Samtidig oppga $55 \%$ at leger bør bidra til å utjevne helseforskjeller $\mathrm{i}$ befolkningen ved å yte ekstra hjelp til pasienter med lav sosioøko- 


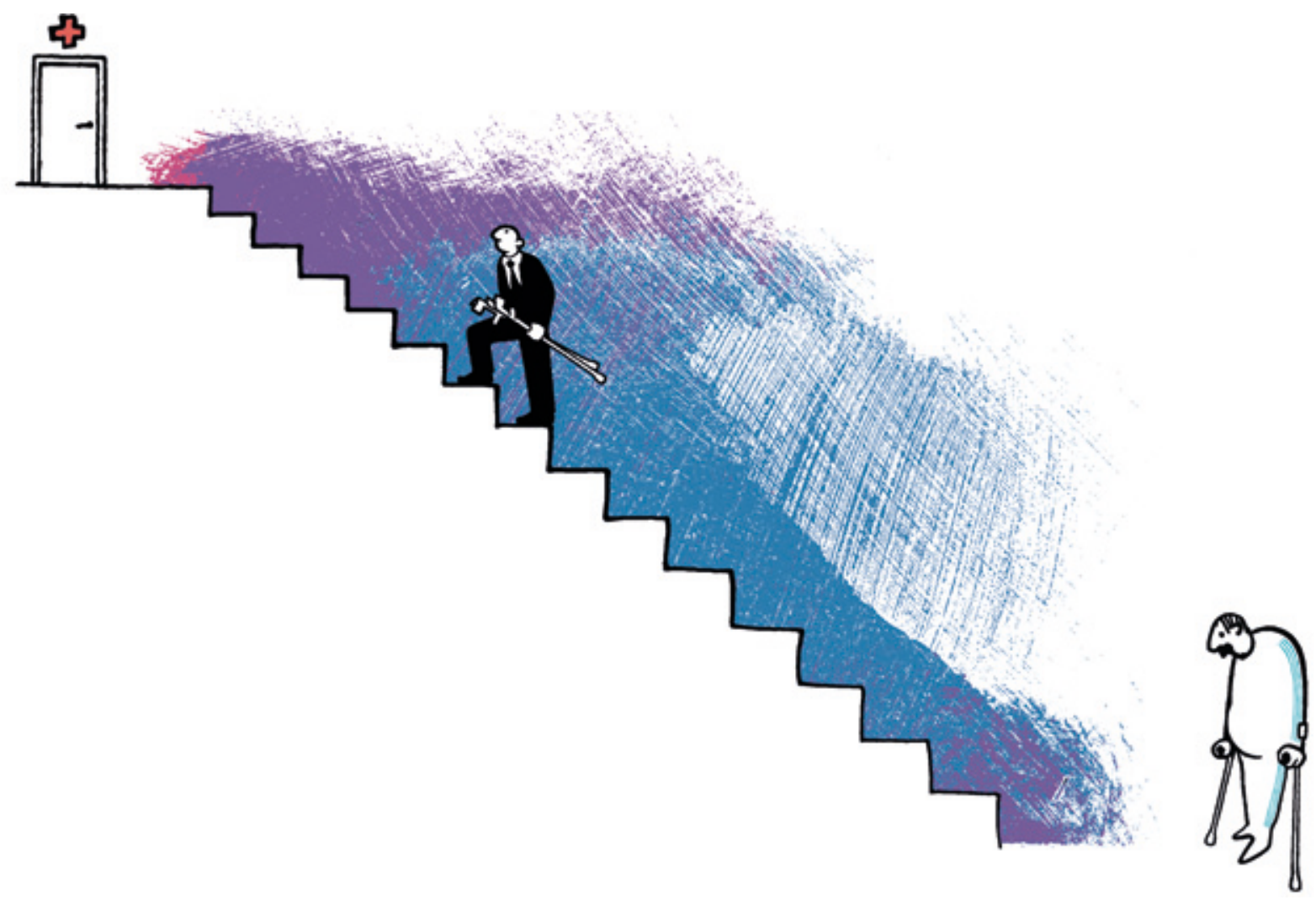

Illustrasjon Supernøtt Popsløyd

nomisk status. Flere momenter ble diskutert for å forklare funnene i artikkelen, bl.a. et uavklart likhetsbegrep for utøvelse av medisinsk praksis. Det er usikkert om leger skal jobbe etter innsatslikhet (lik innsats for alle pasienter) eller resultatlikhet (som vil kreve at man tilpasser pasientbehandlingen avhengig av behov). Flere mener at leger må jobbe etter resultatlikhet, dvs. at man bruker mer ressurser på pasienter med lavere sosioøkonomisk status (13).

Et moment som man ikke tok for seg i artikkelen, var om utdanningen til disse legene hadde tilrettelagt for forståelse av sosioøkonomiske helsefaktorer og formidlet kunnskap om hvordan medisinsk praksis kan bidra til større helselikhet i befolkningen. Grunnutdanningen til helsearbeidere, i tillegg til våre forventninger til og ønsker for yrket, former i stor grad vår forståelse for hvordan medisinsk praksis kan eller bør utøves. Det er imidlertid et stort spørsmål om man i den helsefaglige utdanningen forbereder morgendagens helsearbeidere på å forstå sammenhengen mellom pasientens sykdom og de sosiale forholdene pasientene lever under og hvordan sosiale helseforskjeller vil kunne påvirke pasientbehandling.

\section{Den helsefaglige utdanningen}

The Lancet publiserte i desember 2010 resultatet av en global kommisjon som hadde sett på tilstanden til helsefaglig utdanning og hvilke reformer som er nødvendige for å utstyre helsefagutdanningen for det 21. århundrets utfordringer (14). Rapporten hadde et globalt perspektiv, og slutningene kan regnes som relevant for helsefagutdanning $\mathrm{i}$ alle land. Tverrfaglig samarbeid, mer undervisning i primærog kommunehelsetjeneste, mer vektlegging på helsefremmende arbeid og medisinsk praksis som skal utjevne sosiale helseforskjeller, var stikkord i rapporten. Hvorvidt anbefalingene fra denne rapporten har ført til en mer omfattende prosess hvor man vurderer innhold og målsetninger for den helsefaglige utdanningen slik den er i Norge i dag, vites ikke, annet enn at den helsefaglige utdanningen var et av undertemaene for stortingsmeldingen om morgendagens helsetjeneste.

Det finnes ingen oversikt over innholdet av temaet «sosiale ulikheter i helse» i medisinutdanningen eller annen helsefaglig utdanning, annet enn ev. læringsmål i semesterbøker. Det bør kanskje vurderes om grunnleggende temaer som sosiale ulikheter i helse, etikk, pasientsikkerhet, kommunikasjon og global helse ikke bare skal læres som egne fag i løpet studietiden, men i større grad integreres med klinisk undervisning og sykdomslære. I tillegg må rettferdighetsprinsippet i større grad inn i utdanningen dersom helsearbeidere skal føle og forstå at sosiale ulikheter er noe som angår dem. I engelsk litteratur er bekjempelse av sosiale ulikheter i helse i stor grad forbundet med begrepet «equity». Det er ikke det samme som «equality» som betyr «likhet». «Equity» går mer på rettferdighet og beskriver et rettferdighetsprinsipp som i større grad bør ivaretas i helsetjenesten, f.eks. ved at medisinsk praksis i større grad tilpasses de sosioøkonomiske forholdene som berører pasienten.

Royal College of Physicians i Storbritannia publiserte i 2010 et policynotat med bl.a. forbedringer i utdanningen for å imøtekomme sosiale helseutfordringer (15). Her fremkom en rekke anbefalinger som kan iverksettes av dekanater, fakulteter og andre som er med på å utforme den helsefaglige utdanningen. Disse er veldig relevante også for Norge.

\section{Uløste spørsmål}

Skal helsearbeidere bidra til utjevning av sosioøkonomiske helseforskjeller gjennom særbehandling av pasienter som tilhører en bestemt sosioøkonomisk gruppe, f.eks. i form av mer tid under konsultasjon og mer tid til oppfølging? Skal man bare ta de rent medisinske hensyn til etterretning og ikke gjøre forskjell på kong Salomo og Jørgen Hattemaker? Hvordan kan helsearbeidere lede arbeid som motvirker sosiale ulikheter $\mathrm{i}$ helse og være agenter for forandring av politikk også i andre sektorer som berører helse? Hvilke virkemidler bør benyttes? Og ikke minst, hvilke tiltak er nødvendig for at helsefagsutdanningen skal kunne forberede helsefagsutøvere på de sosioøkonomiske helseutfordringene som de vil komme til å møte ute i praksis?

Disse spørsmålene må avklares, da de er fundamentale for hvor godt helsetjenesten er i stand til å utjevne sosiale helsefor- 
skjeller og forbedre den totale folkehelsen samt hvordan helsefagsutdanningene skal legges opp. Dette vil bli drøftet $i$ et seminar i Helsedirektoratet i september 2011.

Nå, over 100 år etter at Flexner-rapporten ble utgitt, er det sannsynligvis på tide med enda et paradigmeskifte for medisin- og andre helsefagsutdanninger. Man bør nå forvente at studenter ikke bare skal forstå de underliggende patofysiologiske mekanismene som ligger til grunn for sykdom, men også de underliggende sosiale forholdene som bidrar til å påvirke pasienters sykdomsatferd, sykdoms- og behandlingsforløp samt hvordan man kan ta hensyn til disse faktorene når pasientbehandling og medisinsk praksis skal gjennomføres.

\section{Unni Gopinathan (f. 1986)}

er medisinstudent ved Universitetet i Oslo og har verv i Norsk medisinstudentforening. Ingen oppgitte interessekonflikter.

\section{Johanne Helene Iversen (f. 1987)}

er medisinstudent ved Universitetet i Bergen og er internasjonalt ansvarlig i Norsk medisinstudentforening.

Ingen oppgitte interessekonflikter.

\section{Litteratur}

1. CSDH. Closing the gap in a generation: health equity through action on the social determinants of health. Final report of the Commission on Social Determinants of Health. Genève: WHO, 2008.

2. Marmot M. Fair society, healthy lives - strategic review of health inequalities in England post 2010. London: The Marmot Review, 2010.

3. Marmot M. The Status syndrome. How social standing affects our health and longevity. New York. NY: Times Books, 2004.

4. Gradientutfordringen. Sosial- og helsedirektoratets handlingsplan mot sosiale ulikheter i helse. Oslo: Helsedirektoratet, 2005.

5. Flexner A. Medical education in the United States and Canada: a report to the Carnegie Foundation for the Advancement of Teaching. New York, NY: The Carnegie Foundation for the Advancement of Teaching, 1910

6. Declaration of Alma Ata. Alma Ata, Kazakhstan: The International Conference on Primary Health Care, 1978.
7. WHO. Return to Alma Ata. www.who.int/dg/ 20080915/en/index.html (19.6.2011).

8. Grasdal A, Monstad K. Sosial ulikhet i fordelingen av helsetjenester, målemetoder og empiriske funn. I: Haug K, Kaarbøe O, Olsen T. Et helsevesen uten grenser? Oslo: Cappelen Akademisk, 2009.

9. Jensen A. Sosiale ulikheter i bruk av helsetjenester. En analyse fra Statistisk sentralbyrås levekårsundersøkelse om helse, omsorg og sosial kontakt. SSB-rapport nr. 6/2009. Oslo: Statistisk sentralbyrå, 2009

10. St.meld. 20 (2006-2007). Nasjonal strategi for å utjevne sosiale helseforskjeller.

11. Hart JT. The inverse care law. Lancet 1971; 1 405-12.

12. Bringedal B, Bærøe K. Bør leger bidra til å utjevne sosiale ulikheter i helse? Tidsskr Nor Legeforen 2010; 130: 1024-7.

13. Claussen $B$. Legers innvirkning på sosiale ulikheter i helse. Tidsskr Nor Legeforen 2010; 130: 1012.

14. Frenk J, Chen L, Bhutta AZ el al. Health professionals for a new century: transforming education to strengthen health systems in an interdependent world. Lancet 2011; 376: 1923-58.

15. How doctors can close the gap - tackling the social determinants of health through culture change, advocacy and education. London: Royal College of Physicians, 2010. 